\title{
JAPOŃSKA POLĄCZONA FLOTA \\ W I BITWIE POD GUADALCANAL 12-13 LISTOPADA 1942 ROKU
}

Japończycy po udanym starciu artyleryjskim w nocnej bitwie pod Savo 8-9 sierpnia 1942 r. oraz przegranej potyczce koło przylądka Ésperance 11-12 października 1942 r. dalej toczyli ciężkie boje z siłami US Navy o zdobycie dominacji na akwenie okalającym Guadalcanal. Jednym z etapów kampanii w opisywanym rejonie było kolejne nocne starcie nieopodal wyspy. Tym razem po raz pierwszy japoński głównodowodzący admirał Isoroku Yamamoto skierował do walki swoje najcięższe okręty - pancerniki. Opisana niżej I bitwa pod Guadalcanal była jedną z wielu, w której dzięki dobrze zorganizowanemu kontruderzeniu strona amerykańska po raz kolejny odniosła, pomimo poniesionych strat, strategiczne zwycięstwo, tak istotne na tle wszystkich walk toczonych na Guadalcanal.

Przebieg krwawych starć na wyspie zmusił japoński Sztab Połączonej Floty do podjęcia działań o charakterze ofensywnym. Ich wyrazem miały być uzupełnienia pozwalające w niedługim czasie wzmocnić nadwątlone siły Cesarskiej Armii. Do zabezpieczenia planowano wykorzystać jednostki stacjonujące w okolicznych bazach morskich, a do najważniejszych należały Truk i Rabaul. W tym celu w ramach przyjętej w okresie poprzedzającym wybuch wojny na Pacyfiku doktryny współdziałania między armią a marynarką zdecydowano się na przeprowadzenie dużego desantu, którego ubezpieczeniem miały być jednostki wchodzące w skład Połączonej Floty. Łącznie w okresie poprzedzającym bitwę dokonano wzmocnień, a lądowania miały miejsce w dniach 2, 7, 8 i 10 listopada 1942 r. ${ }^{1}$ Przy użyciu szybkich niszczycieli tworzacych „Tokio Express” udało się przerzucić spore uzupełnienia, co należało uznać za niewątpliwy sukces².

Opisane powyżej działania strony japońskiej były odpowiedzią na analogiczne posunięcia Amerykanów z 3 listopada 1942 r. ${ }^{3}$ Desanty te stanowiły wzmocnienie garnizonów i jednoczesne przygotowanie do ostatecznego rozstrzygnięcia na

1 Z. Flisowski, Burza nad Pacyfikiem, t. 1, Poznań 1986, s. 438.

2 T. Hara, Dowódca niszcryyciela, tłum. A. Pogorzelski, Gdańsk 2003, s. 193-194; M. Hashimoto, Zatopieni. Historia japońskiej floty podwodnej 1941-1945, tłum. M. Perzyński, M. Jurczyński, Gdańsk 2013, s. 81.

3 J. Lipiński, Druga wojna światowa na morzu, Warszawa 2010, s. 498. 
Guadalcanal. Stałym tłem działań lądowych był udział jednostek Połączonej Floty dowodzonej przez admirała Isoroku Yamamoto. Głównodowodzący postanowił w celu szybszego zwycięstwa po raz kolejny wysłać podległe mu okręty w okolice niegościnnej wyspy.

Po przeanalizowaniu posunięć strategicznych przeciwnika Yamamoto wraz ze Sztabem Połączonej Floty uznał, że najlepszym terminem na wykonanie następnego dużego desantu będzie noc z 14 na 15 listopada $1942 \mathrm{r}^{4}{ }^{4}$ Ta niezwykle skomplikowana operacja miała być poprzedzona wieloma działaniami o charakterze zaczepnym, mającymi wprowadzić w błąd dowódców amerykańskich. Wśród nich były przygotowania artyleryjskie przewidziane na noce z 12 na 13 oraz z 13 na 14 listopada 1942 r. Do ich realizacji wyznaczono bardzo silny zespół okrętów pod dowództwem wiceadmirała Hiroakiego Abe.

Trzon głównego zespołu odpowiedzialnego za bombardowanie stanowiły 2 pancerniki „Hiei” (okręt flagowy) ${ }^{5}$ i „Kirishima”, lekki krążownik „Nagara” oraz

4 Do realizacji zadania transportowego oddelegowano konwój składający się z 11 transportowców w osłonie 10. Dywizjonu Niszczycieli pod dowództwem niezwykle utalentowanego kontradmirała Raizo Tanaki. Miała to być pierwsza próba wysadzenia na wyspie pełnowartościowego, dużego desantu. Operacja otrzymała kryptonim „I”. Z. Flisowski, Na wodach Guadalcanalu, Poznań 1990, s. 175.

5 Dane techniczne pancernika „Hiei”: rozpoczęcie budowy: 4 listopada 1911 r., oddanie do służby: 4 sierpnia 1914 r. Okręt został poddany modernizacjom w $1931 \mathrm{r}$. oraz w latach 1937-1940. Wyporność standardowa: 33050 t, pełna: 37186 t, dł.: 222 m, szer.: 32 m, zanurzenie: 9,4 m. Siłownia główna: 8 kotłów Kampon Ro-gō, 4 turbiny parowe Kampon o mocy maksymalnej 137970 KM, prędkość maksymalna: 29,9 węzła, zapas paliwa: 6330 ts, zasięg: 10000 Mm przy prędkości 18 węzłów. Uzbrojenie artyleryjskie: $8 \times 356 \mathrm{~mm}(4 \times \mathrm{II}), 14 \times 152 \mathrm{~mm}(14 \times \mathrm{I}), 8 \times 127 \mathrm{~mm}(4 \times \mathrm{II}), 4 \times 76$ $(4 \times \mathrm{I}), 20 \times 25 \mathrm{~mm}(10 \times \mathrm{II})$. Inne wyposażenie: 3 wodnosamoloty patrolowe $(2 \times \mathrm{F} 1 \mathrm{M} 2,1 \times \mathrm{E} 13 \mathrm{~A} 1)$, radar 10 m Typ 94. Załoga 1222 osoby. W momencie I bitwy pod Guadalcanal okrętem dowodził komandor Masao Nishida. Dane na podstawie: O. Myszor, Cesarstwo Japonii. Pancerniki, lotniskowce i krażowniki, t. 1, Tarnowskie Góry 2014, s. 78-79; G. Bukała, Jak aginał pancernik. Hiei? (Z tajemnic marynarki japońskiej), „Morza, Statki i Okręty” 1999, nr 6, s. 31-32.

6 Dane techniczne pancernika „Kirishima”: rozpoczęcie budowy: 17 marca 1912 r., oddanie do służby: 19 kwietnia 1915 r. Okręt został poddany modernizacjom w 1931 r., w latach 1932-1933 oraz w 1939 r. Wyporność standardowa: 32492 t, pełna: 39767 t, dł.: 222 m, szer.: 31 m, zanurzenie: 9,7 m. Siłownia główna: 8 kotłów Kampon Ro-gō, 4 turbiny parowe Kampon o mocy maksymalnej $136940 \mathrm{KM}$, prędkość maksymalna: 29,8 węzła, zapas paliwa: 6403 ts, zasięg: $10000 \mathrm{Mm}$ przy prędkości 18 węzłów. Uzbrojenie artyleryjskie: 8×356 mm (4×II), 14×152 mm (14×I), 8×127 mm (4×II), $7 \times 76 \mathrm{~mm}(7 \times \mathrm{I}), 4 \times 40 \mathrm{~mm}(2 \times \mathrm{II}), 20 \times 25 \mathrm{~mm}(10 \times \mathrm{II}), 8 \times 13 \mathrm{~mm}(2 \times \mathrm{IV})$. Inne wyposażenie: 3 wodnosamoloty patrolowe $(2 \times$ F1M2, $1 \times$ E13A1), radar $10 \mathrm{~m}$ Typ 94, od 1942 r. radar typu 21. Załoga: 1303 osoby. W momencie I bitwy pod Guadalcanal okrętem dowodził komandor Sanji Iwabuchi. Dane na podstawie: O. Myszor, Cesarstwo Japonii..., s. 81-82.

Dane techniczne lekkiego krążownika „Nagara”: rozpoczęcie budowy: 9 września 1920 r., oddanie do służby: 21 kwietnia 1922 r. Okręt został zmodernizowany w 1933 r. Wyporność standardowa: 5253 t, wyporność pełna: 7112 t, dł.: 162,15 m, szer.: 14,2 m, zanurzenie: 4,9 m. Siłownia główna: 12 kotłów Kampon Ro-gō, 4 turbiny parowe Parsons-Gihon o mocy maksymalnej 
11 niszczycieli osłony ${ }^{8}$. Okręty te pochodziły z różnych formacji wyznaczonych do akcji nieopodal Guadalcanal' ${ }^{9}$ Admirał Yamamoto jako daleką osłonę opisanej grupy jednostek wyznaczył siły znajdujące się pod dowództwem wiceadmirała Nobutake Kondo oraz osławionego w bitwie pod Savo wiceadmirała Gunichiego Mikawy, dowódcy 8. Floty. Ponadto w poprzednich bitwach uszczuplono potencjał bazujący na lotniskowcach, dlatego do walki skierowano 25. i 26. Flotyllę Powietrzną stacjonujące w Rabaul. Dysponowały one łączną siłą 215 samolotów.

Równolegle do działań realizowanych przez stronę japońską dużą aktywność w regionie Guadalcanal wykazywały siły US Navy. Prowadzone operacje desantowe wymagały również użycia dużych sił morskich zabezpieczających przed działaniami Połączonej Floty. Należał do nich zespół TF 67.4 pod dowództwem kontradmirała Daniela J. Callaghana, mający w swoim składzie ciężkie krążowniki USS „San Francisco”, USS „Portland”, lekkie krążowniki USS „Atlanta”, USS „Juneau”, USS „Helena” oraz 8 niszczycieli (USS „Cushing”, USS „Laffey”, USS „Sterett”, USS „O’Bannon”, USS „Barton”, USS „Monssen”, USS „Fletcher”, USS „Aaron Ward" ${ }^{10}$. Dodatkowo dowodzący operacją wokół wyspy wiceadmirał William Halsey w celu zwiększenia szans na zwycięstwo Stanów Zjednoczonych wyznaczył do realizacji zadania pancerniki USS „Washington”, USS „South Dakota” i 24 okręty podwodne rozmieszczone w różnych rejonach akwenu ${ }^{11}$.

Wydarzenia, które przeszły do historiografii jako I bitwa pod Guadalcanal, miały swój początek 12 listopada $1942 \mathrm{r}$. Wtedy też około godziny 14.05 doszło do pierwszej interakcji lotnictwa japońskiego z amerykańskim konwojem, który miał dostarczyć kolejne posiłki na wyspę. Ta powietrzno-morska bitwa nie doprowadziła do zniszczenia zespołu transportowego, jednakże wskutek samobójczego ataku uszkodzony

$92670 \mathrm{KM}$, prędkość maksymalna: 34,87 węzła. Uzbrojenie: $7 \times 140 \mathrm{~mm}(7 \times \mathrm{I}), 2 \times 76 \mathrm{~mm}(1 \times \mathrm{II})$, $2 \times 25 \mathrm{~mm}(2 \times \mathrm{I}), 2 \times 13,2 \mathrm{~mm}(2 \times \mathrm{I}), 2 \times 6,5 \mathrm{~mm}(2 \times \mathrm{I}), 8$ wyrzutni torped kalibru $610 \mathrm{~mm}(4 \times \mathrm{II})$. Inne wyposażenie: 1 samolot patrolowy F1M, 3 reflektory o przekątnej lustra $110 \mathrm{~cm}$. Załoga: 37 oficerów, 413 marynarzy. W momencie I bitwy pod Guadalcanal okrętem dowodził komandor Yoshioki Tahara. Dane na podstawie: ibidem, s. 232-233, 240.

8 W skład japońskiej formacji wchodziły niszczyciele: „Akitsuki”, „Amatsukaze”, „Asagumo”, „Harusame”, „Ikazuchi”, „Inazawa”, „Murasame”, „Samidare”, „Teruzuki”, „Yudachi” i „Yukikaze”. T. Hara, Dowódca..., s. 196; G. Bukała, Jak zginat pancernik..., s. 32.

9 Pancerniki „Hiei” i „Kirishima” tworzyły razem Grupę Dywersyjna pod dowództwem wiceadmirała Hiroakiego Abe, lekki krążownik „Nagara” razem z niszczycielami „Amatsukaze”, „Yukikaze”, „Akitsuki”, „Ikazuchi” „Inazawa”, „Teruzuki” tworzyły 10. Eskadrę Niszczycieli pod dowództwem kontradmirała Susumu Kimury. Niszczyciele „Asagumo”, „Murasame”, Samidare”, „Yudachi”, „Harusame” tworzyły 4. Eskadrę Niszczycieli pod dowództwem kontradmirała Tamotosu Takamy. Informacje na podstawie: S.E. Morrison, Guadalcanal, tłum. R. Jędrusik, Gdańsk 2004, s. 233.

10 S. Piereslegin, E. Piereslegin, Premiera na Pacyfiku, t. 2, tłum. J. Wąsiewski, Gdańsk 2006, s. 162.

11 W. Holicki, „Showboat” i Washington czyli koniec "morskich wakacii”, „Morza, Statki i Okręty” 2001, nr 2, s. 44. 
został ciężki krążownik „San Francisco”12. Po odeskortowaniu transportowców kontradmirał Callaghan pozostał w regionie, ponieważ napływały do niego meldunki zwiadu powietrznego o wykryciu wrogich sił rozmieszczonych na północny-zachód od wyspy. Jeszcze w trakcie starcia Amerykanów z samolotami okręty japońskie połączyły się i zbliżały nieuchronnie w kierunku brzegu Guadalcanal ${ }^{13}$.

Wieczorem 12 listopada 1942 r. jednostki US Navy cały czas znajdowały się na patrolu bojowym nieopodal niegościnnej wyspy. Callaghan doskonale zdawał sobie sprawę z faktu, że ciężkie okręty należące do Połączonej Floty zostaną po raz kolejny wykorzystane do ostrzeliwania obiektów strategicznych, a zwłaszcza lotniska Henderson Field, dlatego przygotował zasadzkę. W przypadku Yamamoto i Sztabu Połączonej Floty była to wielokrotnie powtarzana taktyka, a więc na tym etapie wojny ryzykowna i łatwa do przewidzenia. Tajemnica pozostawał tylko skład sił wyznaczonych do bombardowania obiektu. Istotnie do tego momentu inicjatywa strategiczna znajdowała się po stronie US Navy.

Równolegle do działań realizowanych przez Amerykanów japoński dowódca podążał w kierunku Guadalcanal. Jego niezwykle silna eskadra znajdowała się przez cały czas w strefie złej pogody, która stanowiła skuteczną osłonę przed nieprzyjacielskim lotnictwem. Niesprzyjająca aura przyczyniła się w bardzo dużym stopniu do dezorganizacji skomplikowanego kołowego szyku formacji, rozdzielając go na dwie części ${ }^{14}$. W nocy, gdy jednostki wiceadmirała Abe znajdowały się nieopodal wyspy, sytuacja meteorologiczna znacznie się poprawiła.

Krótko po zbliżeniu się na odległość 12 Mm do wybrzeża Guadalcanal japoński dowódca nakazał rozpoczęcie przygotowań do ostrzału lotniska Henderson Field, które stanowiło główny punkt operacji $1^{15}$. Po osiągnięciu gotowości bojowej przez artylerzystów pancerników „Hiei” i „Kirishima” wiceadmirał Abe, płynąc równolegle do wyspy, oczekiwał na zajęcie dogodnej pozycji do ostrzału Henderson Field, co

12 Na skutek uszkodzenia jednego z japońskich samolotów jego pilot skierował maszynę w kierunku ciężkiego krążownika USS „San Francisco”. Maszyna uderzyła w rufową część okrętu, uszkadzając rufową nadbudówkę, centralę artyleryjską oraz wieżę artylerii głównej kalibru $203 \mathrm{~mm}$. Z. Flisowski, Burza..., s. 440; S.E. Morrison, Guadalcanal..., s. 229.

13 Do spotkania jednostek doszło 11 listopada 1942 r. około godziny 15.30. Niszczyciele przypłynęły z bazy na Shortland, natomiast pancerniki z bazy w atolu Truk. T. Hara, Dowódca..., s. 195.

14 Szyk kołowy był bardzo dobrym zabezpieczeniem przed atakami okrętów podwodnych. Jednak jego utrzymywanie, zwłaszcza w fatalnych warunkach pogodowych, stawało się bardzo uciążliwe. Uniemożliwiał on skuteczne wykonywanie zwrotów taktycznych oraz ataków torpedowych przez niszczyciele znajdujące się po bokach formacji. Ibidem, s. 199; S.E. Morrison, Gu adalcanal..., s. 239.

15 Ostrzał miał zniszczyć infrastrukturę lotniska, uniemożliwiając realizację operacji lotniczych. Skuteczne wykonanie zadania miało pozwolić na zniwelowanie amerykańskiej dominacji w powietrzu i wykonanie desantu przez Tanakę. Z. Flisowski, Burza..., s. 441; G. Bukała, Jak zinat pancernik..., s. 34 . 
wymagało jeszcze kilku minut wstrzymania ognia. W tym samym momencie, około godziny 1.34, na pokładzie amerykańskiego lekkiego krążownika „Helena” obsługa radaru zameldowała wykrycie nieprzyjacielskich okrętów w odległości zaledwie $25 \mathrm{~km}$ od zespołu kontradmirała Callaghana ${ }^{16}$. Bitwa miała się wkrótce rozpoczaćć.

W tym najbardziej istotnym dla sił US Navy momencie dały o sobie znać uszkodzenia odniesione w bitwie powietrzno-morskiej, których ofiarą padł ciężki krążownik USS „San Francisco”. Po uprzednim trafieniu przez samolot nie dokonano dokładnych oględzin zniszczeń okrętu, co spowodowało jego niezdolność do szybkiego rozpoczęcia działań zaczepnych. Kontradmirał Callaghan rozpaczliwie usiłował pozyskać dokładne informacje dotyczące nadciagającego wroga. W tym celu za pomocą łączności radiowej kontaktował się z „Heleną”, która przekazywała mu wszystkie dane związane z odległością, szybkością i kursem podejścia wroga. To zamieszanie trwało ponad 8 minut, podczas których nie oddano w kierunku Japończyków ani jednego strzału. Około godziny 1.42 znajdujące się na przedzie obu formacji niszczyciele rozpoczęły ataki torpedowe, a do wiceadmirała Abe dotarł meldunek o wykryciu wrogiej grupy okrętów.

Ta paradoksalna sytuacja spowodowała całkowitą utratę inicjatywy operacyjnej przez amerykańskich dowódców, niwelując jednocześnie przewagę elementu zaskoczenia i wczesnego wykrycia przez radar. Niemałe zamieszanie panowało także w japońskiej formacji. Wiceadmirał Abe o godzinie 1.42 otrzymał meldunek o nawiązaniu kontaktu z wrogiem nadany przez niszczyciel „Yudachi”. W tym momencie jego pancerniki nie były gotowe do oddania salwy w kierunku Amerykanów, ponieważ w komorach ładunkowych dział artylerii głównej kal. 356 mm znajdowały się pociski odłamkowo-burzące przeznaczone do bombardowania lotniska Henderson Field. O godzinie 1.45 obserwator umieszczony na stanowisku dozoru jednego z ciężkich okrętów (prawdopodobnie „Hiei”) zameldował o wykryciu nieprzyjaciela w odległości około $9 \mathrm{~km}$ od pancerników. Dowodzący siłami japońskimi nakazał jak najszybszą zmianę pocisków na przeciwpancerne przeznaczone do starcia artyleryjskiego. Trzy minuty później Callaghan zezwolił wreszcie na otwarcie ognia.

W panującym na polu bitwy zamieszaniu doszło do rozcięcia na dwie części japońskiej formacji przez okręty Callaghana. Jako pierwszy około godziny 1.50 swój reflektor zapalił „Akitsuki”, oświetlając nim nadbudówki lekkiego krążownika USS „Atlanta” ${ }^{17}$. Drugim, który zapalił reflektor, zdradzając tym samym swoją pozycję, był pancernik „Hiei”. Jak się okazało później, obu okrętom za ten błąd przyszło srogo zapłacić.

${ }_{16}$ Lącznie operatorzy radaru zgłosili dwa kontakty. Pierwszy w odległości $25000 \mathrm{~m}$, drugi 32000 m. A. Schom, Wojna na Pacyfiku. Od Pearl Harbour do Guadalcanal, wodzonie, strategia, dyplomacja, tłum. S. Kędzierski, Warszawa 2007, s. 421.

17 W trakcie starcia na pokładzie lekkiego krążownika USS „Atlanta” zginął zwycięzca bitwy koło przylądka Èsperance komandor Norman Scott z niemal całym sztabem. 
Reakcja jednostek TF 67.4 była błyskawiczna. Jako pierwszy salwę artyleryjską w kierunku pancernika oddał lekki krążownik USS „Atlanta”, ale okazała się ona zbyt krótka ${ }^{18}$. Odpowiedź „Hiei” była miażdżąca. Niemal cała burtowa salwa, składająca się z 8 pocisków kal. $356 \mathrm{~mm}$, trafiła krążownik, uszkadzając pechową jednostkę. Odpowiedź US Navy przyszła bardzo szybko. Ogień artyleryjski na „Hiei” skupiły 4 niszczyciele, ostrzeliwując głównie wysokie stanowisko dowodzenia. Pociski wystrzeliwane przez okręty w teorii nie powinny wyrządzić większych szkód, jednakże trafiały w bardzo słabo opancerzone elementy konstrukcji, skutkiem czego na wiekowym pancerniku wybuchły liczne pożary, a doznane szkody uniemożliwiły zachowanie łączności wewnętrznej. W tym samym czasie załoga USS „Atlanta" próbowała ratować zdemolowany okręt ${ }^{19}$.

Atak niszczycieli nie obył się bez strat własnych. Pierwszy z nich USS „Cushing” utracił już na pierwszym etapie starcia ster, a po wykonaniu nieudanego ataku torpedowego został oświetlony przez japoński reflektor i dosłownie rozbity przez ogień artyleryjski ${ }^{20}$. USS „Laffey” po wystrzeleniu niecelnej salwy torpedowej z minimalnej odległości również został wyeliminowany z walki i w efekcie zatonął jeszcze w czasie trwania bitwy ${ }^{21}$. Pozostałe dwa USS „Sterett” i USS „O'Bannon” po wystrzeleniu niecelnych torped i uzyskaniu wielu trafień w „Hiei” na tym etapie starcia nie zostały znacząco uszkodzone ${ }^{22}$.

W trakcie nierównego pojedynku artyleryjskiego niszczycieli z japońskim pancernikiem do akcji weszły ciężkie okręty, w tym flagowy USS „San Francisco”. W zamieszaniu towarzyszącym nocnej bitwie pierwszym celem jednostki okazała się USS „Atlanta”, którą zdaniem Zbigniewa Flisowskiego wzięto za nieprzyjacielski niszczyciel ${ }^{23}$. Przyczyniło się to do pogorszenia fatalnego stanu jednostki. Niedługo po tym nieudanym ataku kolejnym celem krążownika stał się niszczyciel „Akitsuki”, który został praktycznie zniszczony i niedługo potem zatonął. Po tym

18 Zdaniem Zbigniewa Flisowskiego i Tameichiego Hary dopiero trzecia salwa wystrzelona przez USS „Atlanta” okazała się celna. Z. Flisowski, Burza..., s. 445; T. Hara, Dowódca..., s. 206.

19 USS „Atlanta” został trafiony przez torpedę wystrzeloną z niszczyciela „Akitsuki”. J. Lipiński, Druga wojna..., s. 499.

20 Udany ostrzał artyleryjski dokonany przez „Hiei” spowodował wyłączenie z akcji niemal całej artylerii niszczyciela. Następnie okręt został dobity przez niszczyciel „Terutsuki”. A. Schom, Wojna na Pacyfiku..., s. 422.

21 USS „Laffey” odpalił swoje torpedy z odległości nieprzekraczającej $350 \mathrm{~m}$. Po uzyskaniu trafienia głowice nie eksplodowały, ponieważ zadziałał mechanizm odpowiedzialny za zabezpieczenie przed przedwczesnym wybuchem. G. Bukała, Jak zginat pancernik..., s. 35.

22 USS „Sterett” w momencie ataku na „Hiei” miał uszkodzone mechanizm sterowania aparatami torpedowymi i stację radiolokacyjna. Zdaniem Jerzego Lipińskiego salwa torpedowa USS „O’Bannon” była celna i trafiła pancernik. Inne publikacje nie potwierdzaja tych informacji. J. Lipiński, Druga wojna..., s. 500.

23 Z. Flisowski, Burza..., s. 446-447; idem, Na wodach..., s. 190. 
sukcesie kontradmirał Callaghan nakazał otwarcie ognia do płonącego „Hiei”24. Pojedynek artyleryjski obu jednostek odbywał się z bardzo niewielkiej odległości, jednak większość pocisków amerykańskich nie trafiła w cel, upadając zbyt blisko. Dopiero czwarta salwa była skuteczna. Uszkodzony japoński pancernik odpowiedział powolnym nieskoordynowanym ogniem, który początkowo również nie był zbyt celny $^{25}$. Interakcja obu jednostek spowodowała ich ciężkie uszkodzenia, aczkolwiek w przypadku „Hiei” przypieczętowała jego los ${ }^{26}$.

Drugim amerykańskim okrętem, który prowadził ogień w kierunku japońskiego pancernika, był USS „Portland”. W czasie trwania opisywanego starcia na polu bitwy panował całkowitych chaos. Krótko przed swoją śmiercią wiceadmirał Callaghan nakazał wstrzymanie ognia w celu identyfikacji, która z własnych jednostek jest jeszcze w stanie prowadzić skuteczny ostrzał sił Połączonej Floty. Po wznowieniu operacji artyleryjskich USS „Portland” został trafiony w rufę przez japońską torpedę ${ }^{27}$. Uszkodzenia spowodowały wyjście okrętu z szyku i zbliżenie się do płonącego „Hiei”, co wykorzystał skrzętnie dowódca, nakazując ostrzelanie zdemolowanego pancernika.

W tym momencie na polu bitwy pojawił się kolejny japoński olbrzym - „Kirishima”, który po oddaniu kilku niecelnych salw do lekkiego krążownika USS „Juneau” zaczął powoli wycofywać się w kierunku wyspy Savo ${ }^{28}$. W tym samym czasie dowodzący niszczycielem „Amatsukaze” komandor Tameichi Hara dokonał niebywałego czynu. Po wykryciu grupy 4 amerykańskich niszczycieli o godzinie 1.52 wykonał udany atak torpedowy, w wyniku którego błyskawicznie zatopił USS „Barton”29. Drugim bohaterem ostatniego etapu starcia był „Yudachi”, samotnie szarżujący na tę samą grupę jednostek US Navy. Po zadaniu wrogowi dużych uszkodzeń jego wnętrze trawiły pożary. Komandor Hara po wykonaniu zwrotu wykrył kolejny amerykański okręt,

${ }^{24}$ Zdaniem J. Lipińskiego wiceadmirał Abe miał nadać do USS „San Francisco” sygnał „pomyłka”. Był przekonany, że jest ostrzeliwany przez własny okręt. J. Lipiński, Druga wojna..., s. 499.

25 Dopiero trzecia salwa „Hiei” trafiła USS „San Francisco”. Łącznie amerykański ciężki krążownik otrzymał 5 trafień pociskami kalibru $356 \mathrm{~mm}, 15$ - kalibru $152 \mathrm{~mm}$ oraz 7 - kalibru $127 \mathrm{~mm}$. G. Bukała, Jak aginat pancernik..., s. 35.

${ }^{26}$ W wyniku japońskiego ostrzału na ciężkim krążowniku USS „San Francisco” zginął kontradmirał Daniel J. Callaghan oraz większość oficerów dowodzących okrętem. Dwa pociski kalibru 203 mm z USS „San Francisco” trafily „Hiei” w przedział generatorów oraz w pomieszczenie maszynki sterowej. Ibidem, s. 35.

27 Torpeda pochodziła z japońskiego niszczyciela „Yudachi”. W momencie otrzymania trafienia USS „Portland” osłaniał swoim kadłubem uszkodzony ciężki krążownik USS „San Francisco”. T. Hara, Dowódca..., s. 208; S.E. Morrison, Guadalcanal..., s. 245-246.

${ }_{28}$ Zdaniem T. Hary „Kirishima” skutecznie ostrzelała USS „San Francisco”. Efektem tych działań miało być wyeliminowanie z akcji dział artylerii głównej ciężkiego krążownika. T. Hara, Dowódca..., s. 207.

29 Zdaniem J. Lipińskiego ofiarą „Amatsukaze” był USS „Laffey”, USS „Barton” został trafiony łącznie 4 torpedami. J. Lipiński, Druga wojna..., s. 499-500. 
lekki krążownik USS „Juneau” i również ten skutecznie wyłączył z dalszych działań, trafiając w niego jedną z czterech torped ${ }^{30}$. $\mathrm{Na}$ „Amatsukaze” nie obyło się bez strat. Wkrótce po ataku torpedowym okręt wszedł w interakcję z ciężko uszkodzonym USS „San Francisco”, a niebawem został ostrzelany przez lekki krążownik USS „Helena”, który uzyskał dwa bezpośrednie trafienia ${ }^{31}$.

Jeszcze w trakcie pojedynku artyleryjskiego z „Hiei” bardzo trudna sytuacja miała miejsce na drugiej grupie amerykańskich niszczycieli. Wskutek skoordynowanego japońskiego ostrzału oraz salw torpedowych eskadra została bardzo uszczuplona. Do akcji bowiem weszły pozostające dotychczas z tyłu 3 japońskie okręty - „Asagumo”, „Murasame” i „Semidare”. W wyniku starcia mocno uszkodzone zostały USS „Cushing” i USS „Monssen”, które płonęły ${ }^{32}$. Około 3.15 na USS „Cushing” wskutek dalszego rozprzestrzeniania się ognia eksplodowały komory amunicyjne. W niewielkiej odległości od 2 okrętów stał bezwładnie USS „Aaron Ward”, który bardzo ucierpiał z wyniku ataku lekkiego krążownika „Nagara”.

Około godziny 2.12 komandor podporucznik Bruce McCandless, obejmujący dowództwo po kontradmirale Callaghanie oraz zabitym dowódcy USS „San Francisco" komandorze Cassinie Youngu, nakazał przegrupowanie i odwrót z pola bitwy. Niemal identyczną decyzję o godzinie 2.00 podjął wiceadmirał Abe, który cały czas miał nadzieję, że uda się uratować mocno uszkodzony pancernik „Hiei”, czego ostatecznie nie dokonał ${ }^{33}$. Po śmierci niemal wszystkich wyższych oficerów amerykańskich dowództwo nad pozostałościami TF 67.4 przejął komandor Gilbert Hoover na USS „Helena”34. Z nocnej zaciętej bitwy oprócz lekko uszkodzonego okrętu Hoovera niemal nietknięte wyszły niszczyciele USS „Fletcher”, USS „O’Bannon” i USS „Sterett”. Pomimo otrzymanych licznych trafień do armady dołączyły ciężki krążownik USS „San Francisco” oraz lekki krążownik USS „Juneau”35.

30 „Yudachi” jako pierwszy odpalił salwę torpedową w kierunku USS „Juneau”, ale wszystkie torpedy chybiły. Następnie krążownik rozpoczął ostrzeliwać pechowy niszczyciel. Został on uratowany przez celną torpedę z „Amatsukaze”, która zmusiła USS „Juneau” do postawienia zasłony dymnej i wycofania się. Ostatecznie „Yudachi” zatonął następnego dnia po uprzednim ściagnięciu załogi. Z. Flisowski, Burza..., s. 452; A. Schom, Wojna na Pacyfiku..., s. 423.

31 Łącznie „Amatsukaze” stracił 43 członków załogi. T. Hara, Dowódca..., s. 194, 210-211.

32 USS „Monssen” został rozbity przez ogień artyleryjski „Asagumo”. Zdaniem T. Hary amerykański niszczyciel w momencie podchodzenia do japońskiego miał zapalone światła rozpoznawcze w celu identyfikacji. Ibidem, s. 213.

33 Pomimo otrzymania rozkazu od wiceadmirała Nobutake Kondo, aby ciężko uszkodzony okręt wziąć na hol, wiceadmirał Abe w obawie przed atakami lotniczymi w dzień zignorowal polecenie i pozostawił okręt na pastwę amerykańskiego lotnictwa z Guadalcanal. G. Bukała, Jak zinat pancernik..., s. 36 .

34 USS „Helena” został lekko uszkodzony przez 3 japońskie niszczyciele: „Asagumo”, „Murasame” i „Semidare”. M. Kopacz, Druga bitwa morska pod Guadalcanal, „Technika Wojskowa. Historia" 2012, nr 4, s. 28.

35 Uszkodzony USS „Juneau” był eskortowany przez niszczyciel USS „Sterett”. Ibidem, s. 28. 
Ostateczny bilans starcia uwidocznił się dopiero 13 listopada 1942 r. Wtedy też po tym, jak amerykańskie jednostki dobiły lekki krążownik USS „Atlanta”, o godzinie 11.01 japoński okręt podwodny został trafiony 2 torpedami przez uszkodzony lekki krążownik USS „Juneau”, co spowodowało błyskawiczne zatopienie japońskiej jednostki z niemal cała załogą. Bardzo długo trwała także agonia „Hiei”. Pozbawiony napędu i możliwości sterownia pancernik był od godziny 7.20 nieustannie atakowany przez amerykańskie samoloty ${ }^{36}$. Jego los dopełnił się tego samego dnia około $5 \mathrm{Mm}$ od wyspy Savo.

Bilans strat dla obu stron w nocnej bitwie 12-13 listopada 1942 r. był tragiczny. Amerykanie utracili w niej 2 lekkie krążowniki (USS „Atlanta”, USS „Juneau”) oraz 4 niszczyciele (USS „Cushing”, USS „Monssen”, USS „Barton”, USS „Laffey”). Do dzisiaj nie udało się ustalić strat poszczególnych załóg ${ }^{37}$. Jedynym i jednocześnie największym sukcesem kontradmirała Callaghana było zapobieżenie japońskiemu bombardowaniu Henderson Field na Guadalcanal. Straty Połączonej Floty również były bardzo dotkliwe. Zatopiono pancernik „Hiei” oraz niszczyciele „Yudachi” i „Akitsuki" "38. Wiceadmirał Abe nie wykonał powierzonego mu zadania eliminacji amerykańskiego lotniska, co miało niewattpliwy wpływ na przebieg dalszych działań w regionie. Za utratę pancernika i klęskę powierzonej misji wiceadmirał Hiroaki Abe został zdymisjonowany i przeniesiony karnie na Wyspy Macierzyste ${ }^{39}$.

Nocna bitwa 12-13 listopada 1942 r. wykazała bardzo powolną zmianę inicjatywy strategicznej w czasie walk o Guadalcanal. Jej przebieg pozwala na wyciagnięcie wniosków dotyczących powolnie przechylającej się szali zwycięstwa na korzyść Stanów Zjednoczonych. Jednakże należy zauważyć, że bitwa ta była jedną z dotkliwszych klęsk taktycznych w starciach US Navy z Połączoną Flotą. To klasyczne nocne starcie artyleryjskie wymusiło na amerykańskich dowódcach większą koncentrację sił w regionie i udowodniło, że morskie pole bitwy ulegało powolnej ewolucji.

36 Około godziny 10.20 pancernik został trafiony 2 torpedami. Kolejne 2 trafienia dosięgły go o 13.30. „Hiei” otrzymał także 1 trafienie bombą lotnicza. Ostatecznie po zdjęciu żywych członków załogi przez japońskie niszczyciele pancernik zatonął około 18.00. Według informacji zawartych w pracy Siergieja Piereslegina i Eleny Piereslegin (Premiera...) „Hiei” został samozatopiony przez załogę. Zob. też: K. Zalewski, Lotniskowce typu Yorktown, „Morza, Statki i Okręty” 2000 , nr 3, s. 40.

37 Zdaniem Z. Flisowskiego na lekkim krążowniku USS ,Juneau” zginęła niemal cała siedmiusetosobowa załoga. Z. Flisowski, Burza..., s. 455.

38 „Yudachi” został dobity 13 listopada 1942 r. w godzinach porannych przez ciężki krążownik USS „Portland”. J. Lipiński, Druga wojna..., s. 500.

39 Wobec wiceadmirała Hiroakiego Abe wszczęto dochodzenie, które ewidentnie wykazało, że istniała możliwość uratowania „Hiei”. Dowódcę krytykowano także za niewykorzystanie w krytycznym momencie drugiego z pancerników - „Kirishimy”, którego większa aktywność na polu bitwy spowodowałaby całkowitą eliminację sił US Navy. Należy wskazać, że „Hiei” był pierwszym japońskim pancernikiem zatopionym wskutek działań bojowych podczas wojny na Pacyfiku. T. Hara, Dowódca..., s. 194. 
Wyrazem tego był zmierzch ery pancerników i wzrost roli lotnictwa, co potwierdzała zagłada „Hiei”. Z jednej strony uwidoczniła się amerykańska przewaga techniczna, w której za czynnik decydujący należy uznać wyposażanie poszczególnych okrętów w radary. $Z$ drugiej strony jeszcze raz dała o sobie znać dominacja Japonii w nocnych starciach artyleryjskich. Niestety, analiza wydarzeń nocy z 12 na 13 listopada 1942 r. wskazuje na całkowitą klęskę strategiczną strony japońskiej. Połączona Flota pomimo taktycznego zwycięstwa nie osiagnęła żadnych celów strategicznych, pozwalając tym samym na wzmocnienie amerykańskich pozycji na Guadalcanal, co niewątpliwie wpłynęło na dalsze wydarzenia podczas trwającej wojny.

\section{SUMMARY}

THE JAPANESE COMBINED FLEET

IN THE FIRST NAVAL BATTLE OF GUADALCANAL,

NOVEMBER 12-13, 1942

The aim of this article is to present events that took place near Guadalcanal Island during the battle that broke out overnight between November 12 and 13, 1942. During this battle, two forces of the US Navy and the Japanese Combined Fleet clashed. Many dramatic events took place that had a clear influence on its course. The first part presents strategic preparations of the two sides and forces. The second part of the article discusses the course of the overnight clash. The third part discusses the losses on both sides. The result of the clash of November 12-13, 1942, was a tactical victory for Japan, which once again defeated the Americans in an overnight artillery battle. However, strategic victory belonged to the United States as they managed to frustrate all measures and plans of the Combined Fleet. 